(C) 2012. This manuscript version is made available under the CC-BY-NC-ND 4.0 license http://creativecommons.org/licenses/by-nc-nd/4.0/

\title{
Predictive validity of the EuropAsi: Clinical diagnosis or composite scoring?
}

Running head: EuropAsi: Clinical diagnosis or composite scoring?

José J. López-Goñi Ph. D. (1) (corresponding author)

Javier Fernández-Montalvo Ph. D. (1)

Alfonso Arteaga BSc. (1)

(1) Department of Psychology and Pedagogy

Universidad Pública de Navarra

Campus de Arrosadía s/n

31006 Pamplona

Spain

Phone: +34-948169243. Fax: +34-948169891

E-mail: josejavier.lopez@unavarra.es 


\begin{abstract}
This study assessed the correlation between the areas of the Interviewer Severity Rating (ISR) and the areas of the Composite Scores (CS) of the EuropAsi. It evaluated the predictive validity of both types of scoring with regard to completion of treatment. For this purpose, 252 patients were interviewed using the EuropAsi. 38.9\% of patients discontinued treatment. Results indicated a high correlation between various areas of the ISR and the CS, except the legal and family-others scales. Regarding predictive results, patients with a score greater than 3 in the ISR family area were more likely to quit the programme compared to patients with a score lower than 3. Patients with a CS score that was greater than 0.34 in the alcohol-use area were more likely to drop-out of treatment. When both ISR and CS scores were included in the prediction model, the ISR family area was a better predictor.
\end{abstract}

Keywords: EuropAsi; Composite Scores; Interviewer Severity Rating; drop-out rates; treatment; drug dependence 


\section{Introduction}

Drug addiction is a multi-dimensional problem that affects all facets of life for people who suffer from it (Ana et al., 2008; Carroll \& Rounsaville, 2002). However, there is significant variance in the manner in which each patient is affected by addiction. When the specific characteristics of each patient are analysed more thoroughly than during group assessments, different treatment needs can be observed (FernándezMontalvo, López-Goñi, Illescas, Landa, \& Lorea, 2007; Grella, Hser, Joshi, \& Douglas Anglin, 1999; López-Goñi, Fernández-Montalvo, Illescas, Landa, \& Lorea, 2008b; López-Goñi et al., 2010; Ravndal, Vaglum, \& Lauritzen, 2005; Sayre et al., 2002).

Various measurements have been developed to assess patient condition at both the beginning of and during treatment (Carroll \& Rounsaville, 2002; Iraurgi \& González-Saiz, 2002). One of the most commonly used measurements is the European version of the Addiction Severity Index (ASI) (McLellan, Luborsky, Woody, \& O’Brien, 1980), to be referred to as the EuropAsi (Kokkevi \& Hartgers, 1995). The Spanish version was developed by Bobes, González, Sáiz and Bousoño (1996). This measurement involves an interview that is often used from a clinical perspective (e.g., for screening, clinical evaluation, and result evaluation) and from an institutional perspective (e.g., to evaluate programme results, compare treatment mechanisms, compare subpopulations of patients, and compare different contexts of treatment) (González-Saiz et al., 2002; Mäkelä, 2004).

This interview assesses the patient's need for treatment in seven different areas:

a) general medical condition; b) professional and financial situation; c) alcohol consumption; d) other drug consumption; e) legal problems; f) family and social relations; and g) psychological condition. After concluding the interview, the intervention team assesses the patient's need for treatment in each of these areas. The 
Interviewer Severity Rating (ISR) can be used for this assessment. This rating is calculated based on a series of critical items in each of the areas so as to consider the patient's own self-evaluation and the interviewer's judgement, and yields a score ranging from 0 (no problem) to 9 (extreme problems). A higher score indicates a more severe addiction, with severity defined as the need for treatment if there is no current treatment in process or as the implementation of additional treatment if the patient is already receiving some type of intervention. The highly subjective nature of this assessment, as it is based on the treatment team's opinion, has been criticised (Sánchez-Hervás, Secades-Villa, Gómez, Romaguera, \& García-Rodríguez, 2009), so a 2-step assessment method was developed to increase the reliability of the ISR (Bobes et al., 2008).

Various studies have examined the psychometric properties of the ASI (McLellan et al., 1985; Mäkelä, 2004), the EuropAsi (Mäkelä, 2004), and the Spanish version of the ASI (González-Saiz, et al., 2002). Generally, the results of the studies indicate some adequate psychometric properties. However, the ISR is generally not recommended for measuring results in the research sector or in programme evaluation studies. Composite Scores (CSs) should be used in the place of the ISR (Bobes, et al., 2008; Kokkevi \& Hartgers, 1995).

The CS was developed to obtain ratings that would facilitate the comparison of results from different treatment programmes. These ratings are arithmetically developed indicators based on information provided by the patients about their activities over the past 30 days, and about their perceived need for help (Koeter \& Hartgers, 1997; McLellan, et al., 1985). The European version of the ASI is composed by 9 CS scales. This is because there are two scales (employment status and family situation), each of which are divided in two subscales: economic situation and employment satisfaction; and family relationships and relationships with others respectively. The ratings range of the EuropAsi: Clinical diagnosis or composite scoring? Journal of Substance

Abuse Treatment, 42, 392-399. http://dx.doi.org/10.1016/j.jsat.2011.09.011 
from 0.00 to 1.00 , with higher values indicating greater severity of each area. It is important to note that the different subscales are not standardised, meaning that similar values between the different areas do not indicate similar severity. Typically, there is a high level of internal consistency for alcohol consumption, medical areas, and psychiatric areas. There is a low level of consistency for the other areas (Mäkelä, 2004). Romelsjo (2004) found a low correlation between the severity of the addiction and the CS.

Nevertheless, there is still some support for the use of the ISR in the research sector. Mäkelä (2004) argues that the usefulness of CSs has been overestimated. In particular, there are 3 major problems with CSs (Melberg, 2004): 1) The scores do not provide a clear profile of each patient's global situation in that the ratings between the different areas cannot be compared for a single case. The ISR provides comparable scores. 2) It is difficult to interpret the scope of changes in the scores. 3) The scores are based on events from the previous 30 days, thereby ignoring elements of the patient's life that can condition his/her evolution. These elements are typically taken into account by a general practitioner when he/she plans future treatment. However, the recommendation to avoid the use of the ISR in the research sector has been overgeneralised to apply to any use, including evaluating patients' results or programme results. In contrast, it has been argued that ISRs are more useful than CSs in some specific contexts, for example in therapeutic communities (Soyez, De Leon, Broekaert, \& Rosseel, 2006). It is also possible to use both ISRs and CS as measures of severity of drug addiction (Davis et al., 2002).

In fact, when the Spanish version of the ISR was used, results were generally positive for both the involved treatment teams and with regard to research on drug addiction treatment (Casares-Lopez et al., 2010; Fernández-Montalvo, Lorea, López- 
Goñi, \& Landa, 2008; Fernández-Montalvo \& López-Goñi, 2010; Graña, Muñoz, \& Navas, 2009; Landa, Fernández-Montalvo, López-Goñi, \& Lorea, 2006; López-Goñi, Fernández-Montalvo, Illescas, Landa, \& Lorea, 2008a). From a clinical perspective, this finding confirms that a clinical diagnosis is necessary to determine a psychopathological diagnosis (Fernández-Montalvo \& Echeburúa, 2006). A good diagnosis is also imperative for guiding treatment in an appropriate manner. Internationally, there are at least two studies that provide interesting results for the clinical sector that have made use of both the ISR and CSs simultaneously (Soyez, et al., 2006; Walton-Moss \& McCaul, 2006).

Research has focused on analysing the relationship between ISRs and CSs. In the ASI, some moderate correlations have been found between the two types of scoring (Alterman, Brown, Zaballero, \& McKay, 1994). With regard to the EuropAsi, the German version has shown high correlations between ISRs and CSs, as well as good inter-rater reliability (Scheurich et al., 2000; Weiler, Vogt, \& Küfner, 2000). Results have also been obtained for the Hungarian version that shows statistically significant correlations of a high magnitude between the 2 types of scoring (Gerevich, Baskai, Ko, \& Rozsa, 2005). In contrast, the Norwegian version specified modifications to improve construct validity and reliability (Lauritzen \& Ravndal, 2004).

A Spanish study analysed the relationship between the two types of scoring (Sánchez-Hervás, et al., 2009). The authors concluded that it was not advisable in the research sector to use the ISR to measure results. This study compared the values within the different CS sections. However, as mentioned previously, the CS scores obtained are not comparable across sections. Consequently, the conclusions obtained in this study must be considered with caution. No other Spanish study has been conducted to directly compare the correlation between the two types of scoring. 
The current study has two goals: First, from a psychometric perspective, it aims to assess the relationship between the different areas of the ISR, and the corresponding areas of the CS. Second, from a clinical perspective, it will compare the predictive validity of both types of scoring with regard to treatment drop-out rates. It should be kept in mind that the primary use of the EuropAsi is to personalise treatment for each patient. A good indicator of a successful match between patient and treatment is treatment completion. Although several studies have assessed the predictive usefulness of the ISR (Fernández-Montalvo \& López-Goñi, 2010) or of the CS (Casares-Lopez, et al., 2010; López-Goñi et al., 2011), this will be the first published study to compare the predictive validity of the two types of ratings.

\section{Method}

The protocol for this study was approved by the ethics committees of the Public University of Navarra and of the Fundación Proyecto Hombre de Navarra.

\subsection{Subjects}

The sample consists of 252 consecutive addicted patients who came to the Fundación Proyecto Hombre de Navarra (Spain) to obtain outpatient treatment between October 2008 and July 2010. The treatment is individually based and aimed at withdrawal from drug use.

The admission criteria for subjects in this study were that they must: a) fulfil the diagnostic criteria for substance addiction disorder according to the DSM-IV-TR (American Psychiatric Association, 2000); b) be between the ages of 18 and 65 years; c) be enrolled in the treatment programme; and d) sign a consent form to participate.

The patients' average age was 37.6 years $(S D=9.5)$, with $203(80.5 \%)$ men and 49 (19.5\%) women. The rate of patients who dropped out of the intervention 
programme was $38.9 \%$ of the sample $(\mathrm{N}=98)$. The main characteristics of the sample are described in table 1.

Insert Table 1 here

\subsection{Evaluation}

Subjects were evaluated with the EuropAsi (Kokkevi \& Hartgers, 1995). As previously discussed, the EuropAsi is the European version of the Addiction Severity Index (ASI) (McLellan, et al., 1980). The Spanish version was developed by Bobes, González, Sáiz and Bousoño (1996). For the current study, both the ISR and CS were used.

\subsection{Procedure}

After selecting the sample according to the admission criteria, the subjects were interviewed by clinical psychologists who had seven or more years of experience in treating addictions and in applying the EuropAsi. Following interviews, the ISR was calculated according to the 2-step methodology suggested by Bobes et al. (2008). Moreover, each subject's CS was calculated by a computerised system, according to the method developed by Koeter \& Hartgers (1997). This method has been used in different studies (De Wilde et al., 2004; Haasen et al., 2009; McSweeney, Stevens, Hunt, \& Turnbull, 2007). Detailed tracking of each subject's progress was also maintained. The goal of this study was to assess whether the subject completed the treatment by obtaining a therapeutic discharge or whether the subject dropped out (i.e., abandoned the treatment before obtaining a therapeutic discharge) of treatment before the conclusion of the programme.

\subsection{Data Analysis}

Descriptive analyses were conducted for all variables. To assess the level of relationship between the ISR and the CS, a Pearson's correlation index was used. For 
bivariate analyses, $\chi^{2}$ tests or t tests were used depending on the nature of the variables being analysed, with a probability of less than 0.05 considered significant. Regarding multivariate analysis, first a logistic regression (step by step forward model) was carried out in order to know if the two scores (ISR and CS) were additive. Second, a CHAID analysis was applied as a post-hoc test to explain significant OLS. Both analyses used the following models: 1) ISR discriminating ability; 2) CS discriminating ability; and 3) discriminating ability of ISR and CS together. All statistic analyses were conducted with the SPSS programme (version 15.0).

\section{Results}

\subsection{Scoring in the EuropAsi}

Table 2 presents the results obtained from the EuropAsi. For the ISR, the highest subscale refers to alcohol consumption and the lowest subscale refers to legal problems. For the CS, the scoring oscillated between 0.11 and 0.38 . However, it is important to note that in the CS, the various areas cannot be compared to one another.

\section{Insert Table 2 here}

As for the progress of subjects during treatment, a total of 98 subjects (38.9\%) dropped out of the programme prior to completion. Regarding the ISRs, subjects who dropped out of treatment showed more severity in their alcohol consumption, in family and/or social issues, and in psychiatric issues at the time of enrolment. However, those who completed the treatment showed a higher severity in drug consumption.

When comparing the two groups in the CS, subjects who dropped out of treatment had more problems related to professional dissatisfaction, alcohol abuse, and family conflicts.

\subsection{Correlation between the ISR and CS}


Table 3 presents the correlations between the ISR and CS, and reveals that apart from the legal area, all ISRs are correlated to their corresponding areas in CSs. These significant correlations vary between 0.728 on the $d r u g$ area and 0.314 on the relationsothers area.

Insert Table 3 here

\subsection{Prediction of Therapeutic Results}

The results of the analyses carried out in order to establish the discriminating ability of the different models are presented in Table 4. Regarding logistic regression analysis, the higher relative predictive ability came from the model 3 (ISR + CS).

\section{Insert Table 4 here}

The results of the CHAID analysis with the three assessed models (ISR, CS or ISR + CS) showed two statistically significant variables: the family area of the ISR and the alcohol area of the CS. When ISRs were included as independent variables (model 1), a rating higher than 3 on the family area suggested that the probability that a subject would drop out of treatment was doubled When CSs were included as independent variables (model 2), the dropout probability increased if the rating for alcohol consumption was higher than 0.34 . When both ISRs and CSs were incorporated (model 3), the variable that explained the difference between dropouts and therapeutic successes was the family scale of the ISR.

\section{Discussion}

This study provides evidence that the CSs and the ISRs produce unique and additive information about patients' condition. The ISRs provide useful information that must be considered, because the judgments based on the CS alone may ignore clinically important information either in treatment planning, or in research. 
Moreover, this study shows the usefulness of the EuropAsi when determining whether patients will successfully complete drug addiction treatment. As is evident from previous studies (Fernández-Montalvo \& López-Goñi, 2010; López-Goñi, et al., 2010), patients who drop out of treatment generally have higher ratings on the different areas of the EuropAsi. It is logical to conclude that patients who have more difficulty, which both the ISR and CS are sensitive to, drop out of treatment at a larger proportion than patients who do experience difficulty. Therefore, it is imperative to integrate improvements in the treatment of addiction so that patients, both with and without difficulties, will complete the programmes.

In this study, patients with major problems on the ISRs in the areas of alcohol consumption, family/social relations, and psychiatry were more likely to drop out of treatment. In contrast, patients who had more severe CS ratings on alcohol consumption across the previous 30 days, more professional dissatisfaction, and more family/social issues were also more likely to dropout. Both perspectives are compatible and provide directions for areas to implement improvements in the assessed treatment programme. Across both rating types, the family area of the ISR is revealed as the breaking point in which the treatment dropout probability is doubled (family $>3,51.4 \%$ vs. family $\leq 3$, 25.4\%). The fewer the family issues, the higher the probability is that a patient will complete the treatment.

This study also provides evidence regarding the high correlation (with values higher than 0.53) in five of the seven assessed areas in the ISRs and CSs for an outpatient drug addiction treatment programme in Spain. This finding supports similar results from other studies (Alterman, et al., 1994; Mäkelä, 2004; Scheurich, et al., 2000). The low correlation (0.367) between the ISR family area and the CS others area indicates that an independent assessment of family relations and social relations (e.g., 
friends, colleagues, and neighbours) should be included in the ISR. In a Spanish context, it is common to treat patients with strong social support and weak family support, or vice versa. Future research should continue to focus on investigating the relationship between these areas. Anyway, the only area not correlated with another was the legal area (0.014). Given that the correlations between areas that do not match are low, this may provide support for independence between the areas assessed by the EuropAsi (McLellan, et al., 1985).

With regard to the predictive value of the ISR and the CS towards patient treatment progress, it appears that both types of scoring can provide relevant information and valuable feedback to the treatment team that supports improvement of specific actions. Both ISRs and CSs have strengths and weaknesses given that they examine different aspects of the same phenomenon. Accordingly, various indices based on distinct items of the ASI or the EuropAsi have been developed (Sizoo et al., 2010; Soyez, et al., 2006), which paves the way for new uses for these measurements.

The results of this study also provide support for the usefulness of the ISR both in the clinical and in the research sector, as has been found in previous studies (Davis, et al., 2002). It is contradictory that using ratings based on the addicted patients' answers (CS) is recommended, whereas other ratings (ISR) based on the clinical impressions of those who will be assigned to treat addicted patients are relegated. Both the patient and the practitioner are essential elements of treatment, and each perspective is important. In this respect, there can be various differences between this study and other studies that have not found a positive relationship between ISRs and CSs (Sánchez-Hervás, et al., 2009). One of these differences is methodological. The validity criterion used in this study was whether the patients completed treatment. Another difference could be associated with the experience and training of the treatment team (with a large amount 
of experience evident in the team for this study). A third difference could be due to the manner in which the ISRs were assessed (although the 2-step way is specified in the manual, some teams only follow the interviewer's criterion). Factors such as these can negatively affect the reliability of the ISR.

This study has various limitations that must be taken into consideration. The first limitation is methods of calculating the ISR and CS. The ISR's rating was based on the interviewer's clinical opinion, which can result in a self-fulfilling prophecy for the patient. Several authors note that the most difficult patients can receive a less intense treatment than they should, often because it is more likely that their appointments are postponed or cancelled (Hall, Popkin, Devaul, \& Stickney, 1977). The CS rating was based on statements made by patients regarding their own behaviour over the previous 30 days. It is relatively frequent to find patients who either try to simulate more severity or try to dissimulate the severity of their behaviour, both of which affect the validity of the CS. Another limitation is related to the sample assessed in this study. Even with a relatively large sample of patients, this sample is primarily composed of patients who ask to be treated for consumption of different substances, which may not be representation of the general addicted population. Moreover, only $20 \%$ of the sample was women. For this reason, some caution must be taken regarding the generalisation of the results obtained. Lastly, the use of patients' successful completion of treatment as the variable being analysed with regard to the predictive validity of the ISRs and CSs also limits the generalisation of these results. Future research should assess the predictive validity of these measurements regarding potential relapses after treatment completion. Overall, the main objective of the treatment programmes should be patient recovery, and not just treatment completion. 
In conclusion, a sixth version of the ASI has recently been introduced in which ISRs were eliminated (Mesa et al., 2010). If similar results to this study are presented in the future, it may be possible to reconsider this elimination. The ISRs could constitute another tool for assessment these patients. A solid and accurate assessment criterion could help clinicians to design tailored programs for this kind of patients.

\section{Acknowledgements}

This work was funded with the help of a research grant from the Ministry of Science and Innovation (code PSI2009-08500). The authors would like to thank the members of the Aldatu treatment team from the Fundación Proyecto Hombre de Navarra for their contributions towards developing this work.

López-Goñi, J.J., Fernández-Montalvo, J. y Arteaga, A. (2012). Predictive validity 14 of the EuropAsi: Clinical diagnosis or composite scoring? Journal of Substance 


\section{Bibliographical References}

Alterman, A. I., Brown, D., Zaballero, A., \& McKay, J. R. (1994). Interviewer severity ratings and composite scores of the ASI: a further look. Drug and Alcohol Dependence, 34, 201-209.

American Psychiatric Association. (2000). Diagnostic and statistical manual of mental disorders (4th Ed. Rev.). Washington, D.C.: APA.

Ana, E. J. S., Martino, S., Ball, S. A., Nich, C., Frankforter, T. L., \& Carroll, K. M. (2008). What is usual about "treatment-as-usual"? Data from two multisite effectiveness trials. Journal of Substance Abuse Treatment, 35, 369-379.

Bobes, J., Bascarán, M. T., Bobes-Bascarán, M. T., Carballo, J. L., Díaz, E. M., Flórez, G., .. . Sáiz, P. A. (2008). Valoración de la gravedad de la adicción: aplicación a la gestión clínica y monitorización de los tratamientos [Assessment of the severity of addition: application to clinical management and treatment monitoring]. Barcelona: Socidrogalcohol.

Bobes, J., Gónzález, M. P., Sáiz, P. A., \& Bousoño, M. (1996). Índice europeo de severidad de la adicción: EuropASI. Versión española [European index of severity of addition: EuroASI. Spanish Version]. Paper presented at the Actas de la IV Reunión Interregional de Psiquiatría.

Carroll, K. M., \& Rounsaville, B. J. (2002). On beyond urine: clinically useful assesment instruments in the treatment of drug dependence. Behaviour Research and Therapy, 40, 1329-1344.

Casares-Lopez, M. J., Gonzalez-Menendez, A., Torres-Lobo, M., Secades-Villa, R., Fernandez-Hermida, J. R., \& Alvarez, M. D. (2010). Comparison of the psychopathological and addictive profile of two samples of addicts in treatment: 
prison and therapeutic community. International Journal of Clinical and Health Psychology, 10, 225-243.

Davis, T. M., Carpenter, K. M., Malte, C. A., Carney, M., Chambers, S., \& Saxon, A. J. (2002). Women in addictions treatment: comparing VA and community samples. Journal of Substance Abuse Treatment, 23, 41-48.

De Wilde, J., Soyez, V., Broekaert, E., Rosseel, Y., Kaplan, C., \& Larsson, J. (2004). Problem severity profiles of substance abusing women in European Therapeutic Communities: Influence of psychiatric problems. Journal of Substance Abuse Treatment, 26(4), 243-251.

Fernández-Montalvo, J., \& Echeburúa, E. (2006). Uso y abuso de los autoinformes en la evaluación de los trastornos de personalidad [Use and abuse of self-reports in assessing personality disorders]. Revista de Psicopatología y Psicología Clínica, $11,1-12$.

Fernández-Montalvo, J., Lorea, I., López-Goñi, J. J., \& Landa, N. (2008). Comorbilidad psicopatológica en la adicción a la cocaína: resultados con el SCL-90-R [Psychopathological comorbidity in cocaine addiction: results with the SCL-90R]. Behavioral Psychology/Psicología Conductual, 16, 273-286.

Fernández-Montalvo, J., \& López-Goñi, J. J. (2010). Comparison of completers and dropouts in psychological treatment for cocaine addiction. Addiction Research \& Theory, 18, 433-441.

Fernández-Montalvo, J., López-Goñi, J. J., Illescas, C., Landa, N., \& Lorea, I. (2007). Relapse precipitants in addictions: Results in a therapeutic community. Journal of Addictive Diseases, 26, 55-61. 
Gerevich, J., Baskai, E. B., Ko, J., \& Rozsa, S. N. (2005). Reliability and validity of the Hungarian version of the European addiction severity index - Results of a multifocal research project. Psychopathology, 38, 301-309.

González-Saiz, F., Salvador, J. M., Martínez-Delgado, J. M., López-Cárdenas, a., Ruz, I., \& Guerra, D. (2002). El Addiction Severity Index (ASI): a propósito de una revisión [A review about Addiction Severity Index (ASI)]. In I. Iraurgi \& F. González-Saiz (Eds.), Instrumentos de evaluación en drogodependencias [Substance abuse assessment tools]. Madrid: Aula Médica Ediciones.

Graña, J. L., Muñoz, J. J., \& Navas, E. (2009). Normal and pathological personality characteristics in subtypes of drug addicts undergoing treatment. Personality and Individual Differences, 46, 418-423.

Grella, C. E., Hser, Y. I., Joshi, V., \& Douglas Anglin, M. (1999). Patient histories, retention, and outcome models for younger and older adults in DATOS. Drug and Alcohol Dependence, 57, 151-166.

Haasen, C., Schulte, B., Vanderplasschen, W., Verthein, U., Schäfer, I., \& Reimer, J. (2009). Predictive value of regular cocaine use among opioid-dependent patients for long-term outcome: A 4-year follow-up study. Addictive Disorders and their Treatment, 8(2), 74-79.

Hall, R. C. W., Popkin, M. K., Devaul, R., \& Stickney, S. K. (1977). The effect of unrecognized drug abuse on diagnosis and therapeutic outcome. American Journal of Drug and Alcohol Abuse, 4, 455-465.

Iraurgi, I., \& González-Saiz, F. (2002). Instrumentos de evaluación en drogodependencias [Substance abuse assessment tools]. Madrid: Aula Médica Ediciones. 
Koeter, M. W. J., \& Hartgers, C. (1997). European Addiction Severity Index EuropAsi. Cost a6. Preliminary procedure for the computation of the europasi composite scores. The Amsterdam Institute for Addiction Research. http://www.emcdda.europa.eu/html.cfm/index3647EN.html

Kokkevi, A., \& Hartgers, C. (1995). European adaptation of a multidimensional assessment instrument for drug and alcohol dependence. European Addiction Research, 1, 208-210.

Landa, N., Fernández-Montalvo, J., López-Goñi, J. J., \& Lorea, I. (2006). Comorbilidad psicopatológica en el alcoholismo: un estudio descriptivo [Psychopathological comorbidity in alcoholism: a descriptive study]. International Journal of Clinical and Health Psychology, 6, 253-269.

Lauritzen, G., \& Ravndal, E. (2004). Introduction of the EuropAsi in Norway: Clinical and research experiences from a cost-effectiveness study. Journal of Substance Use, 9(3-4), 141-146.

López-Goñi, J. J., Fernández-Montalvo, J., Illescas, C., Landa, N., \& Lorea, I. (2008a). Determining socio-demographic predictors of treatment dropout: results in a therapeutic community. International Journal of Social Welfare, 17, 374-378.

López-Goñi, J. J., Fernández-Montalvo, J., Illescas, C., Landa, N., \& Lorea, I. (2008b). Razones para el abandono del tratamiento en comunidad terapéutica: un estudio en Proyecto Hombre [Reasons for discontinuation of treatment in therapeutic communities: a study in Proyecto Hombre]. Trastornos Adictivos, 10, 104-111.

López-Goñi, J. J., Fernández-Montalvo, J., Menéndez, J. C., Yudego, F., García, A. R., \& Esarte, S. (2010). Group and individual change in the treatment of drug addictions: A follow-up study in therapeutic communities. Spanish Journal of Psychology, 13, 906-913.

López-Goñi, J.J., Fernández-Montalvo, J. y Arteaga, A. (2012). Predictive validity 18 of the EuropAsi: Clinical diagnosis or composite scoring? Journal of Substance

Abuse Treatment, 42, 392-399. http://dx.doi.org/10.1016/j.jsat.2011.09.011 
López-Goñi, J. J., Fernández-Montalvo, J., Menéndez, J. C., Yudego, F., Rico, A., \& Esarte, S. (2011). Employment integration after therapeutic community treatment: A case study from Spain. International Journal of Social Welfare, 20, 292-297.

McLellan, A. T., Luborsky, L., Cacciola, J., Griffith, J., Evans, F., Barr, H. L., \& O’Brien, C. P. (1985). New data from the Addiction Severity Index. Reliability and validity in three centers. The Journal of Nervous and Mental Disease.

McLellan, A. T., Luborsky, L., Woody, G. E., \& O’Brien, C. P. (1980). An improved diagnostic evaluation instrument for substance abuse patients: The Addiction Severity Index. The Journal of Nervous and Mental Disease 168, 26-33.

McSweeney, T., Stevens, A., Hunt, N., \& Turnbull, P. J. (2007). Twisting arms or a helping hand? Assessing the impact of 'coerced' and comparable 'voluntary' drug treatment options. British Journal of Criminology, 47(3), 470-490.

Melberg, H. O. (2004). Three problems with the ASI composite scores. Journal of Substance Use, 9(3-4), 120-126.

Mesa, E. M. D., Garcia-Portilla, P., Saiz, P. A., Bascaran, T. B., Casares, M. J., Fonseca, E., . . . Bobes, J. (2010). Rendimiento psicométrico de la sexta versión del Addiction Severity Index en español (ASI-6) [Psychometric performance of the sixth version of the Spanish Addiction Severity Index (ASI-6)]. Psicothema, 22, 513-519.

Mäkelä, K. (2004). Studies of the reliability and validity of the Addiction Severity Index. Addiction 99, 398-410.

Ravndal, E., Vaglum, P., \& Lauritzen, G. (2005). Completion of long-term inpatient treatment of drug abusers: A prospective study from 13 different units. European Addiction Research, 11, 180-185.

López-Goñi, J.J., Fernández-Montalvo, J. y Arteaga, A. (2012). Predictive validity 19 of the EuropAsi: Clinical diagnosis or composite scoring? Journal of Substance

Abuse Treatment, 42, 392-399. http://dx.doi.org/10.1016/j.jsat.2011.09.011 
Romelsjo, A. (2004). The addiction severity index (ASI) and the severity of dependence: How large are the associations? Journal of Substance Use, 9(3-4), 127-131.

Sayre, S. L., Schmitz, J. M., Stotts, A. L., Averill, P. M., Rhoades, H. M., \& Grabowski, J. J. (2002). Determining predictors of attrition in an outpatient substance abuse program. American Journal of Drug and Alcohol Abuse, 28, 55-72.

Scheurich, A., Muller, M. J., Wetzel, H., Anghelescu, I., Klawe, C., Ruppe, A., . . . Szegedi, A. (2000). Reliability and validity of the German version of the European Addiction Severity Index (EuropASI). Journal of Studies on Alcohol, 61, 916-919.

Sizoo, B., van den Brink, W., Koeter, M., van Eenige, M. G., van WijngaardenCremers, P., \& van der Gaag, R. J. (2010). Treatment seeking adults with autism or ADHD and co-morbid Substance Use Disorder: Prevalence, risk factors and functional disability. Drug and Alcohol Dependence, 107, 44-50.

Soyez, V., De Leon, G., Broekaert, E., \& Rosseel, Y. (2006). The impact of a social network intervention on retention in Belgian therapeutic communities: a quasiexperimental study. Addiction, 10, 1027-1034.

Sánchez-Hervás, E., Secades-Villa, R., Gómez, F. J. S., Romaguera, F. Z., \& GarcíaRodríguez, O. (2009). Addictive Severity in Cocaine Addicts Measured with the EuropASI: Differences between Composite Scores and Severity Ratings. The American Journal on Addictions, 18, 375-378.

Walton-Moss, B., \& McCaul, M. E. (2006). Factors associated with lifetime history of drug treatment among substance dependent women. Addictive Behaviors, 31, 246-253.

López-Goñi, J.J., Fernández-Montalvo, J. y Arteaga, A. (2012). Predictive validity 20 of the EuropAsi: Clinical diagnosis or composite scoring? Journal of Substance

Abuse Treatment, 42, 392-399. http://dx.doi.org/10.1016/j.jsat.2011.09.011 
Weiler, D., Vogt, M., \& Küfner, H. (2000). Anwendung des European Addiction Severity Index (EuropASI) im Rahmen einer ambulanten Behandlung von Drogenabhängigen [Application of the European Addiction Severity Index (EuroASI) as part of outpatient treatment of drug addicts]. SUCHT-Zeitschrift für Wissenschaft und Praxis/Journal of Addiction Research and Practice, 46, 197-208. 
Table 1. Characteristics of the sample

\begin{tabular}{|c|c|c|c|c|c|c|c|}
\hline & \multicolumn{2}{|c|}{$\begin{array}{c}\text { All } \\
\mathrm{N}=252\end{array}$} & \multicolumn{2}{|c|}{$\begin{array}{l}\text { Therapeutic discharge } \\
\text { (n = 154) }\end{array}$} & \multicolumn{2}{|c|}{$\begin{array}{l}\text { Drop-out } \\
(\mathrm{n}=98)\end{array}$} & \multirow[b]{2}{*}{$t$} \\
\hline & Mean & (SD) & Mean & (SD) & Mean & (SD) & \\
\hline \multirow[t]{3}{*}{ Mean age } & 37.6 & $(9.5)$ & 36.8 & 9.4 & 38.7 & 9.5 & 1.5 \\
\hline & \multicolumn{2}{|c|}{$\begin{array}{c}\text { All } \\
(\mathrm{N}=252)\end{array}$} & \multicolumn{2}{|c|}{$\begin{array}{l}\text { Therapeutic discharge } \\
\qquad(\mathrm{n}=154)\end{array}$} & \multicolumn{2}{|c|}{$\begin{array}{l}\text { Drop-out } \\
(\mathrm{n}=98)\end{array}$} & \\
\hline & $\mathbf{N}$ & $(\%)$ & n & (\%) & n & (\%) & $X^{2}$ \\
\hline \multicolumn{8}{|l|}{ Sex } \\
\hline Men & 203 & $(80.5 \%)$ & 126 & $(81.8 \%)$ & 77 & $(78.6 \%)$ & \multirow{2}{*}{.4} \\
\hline Women & 49 & $(19.5 \%)$ & 28 & $(18.2 \%)$ & 21 & $(21.4 \%)$ & \\
\hline \multicolumn{8}{|l|}{ Marital Status } \\
\hline Single & 122 & $(48.4 \%)$ & 71 & (46.1\%) & 51 & $(52.0 \%)$ & \multirow{4}{*}{3.6} \\
\hline Married & 76 & $(30.2 \%)$ & 53 & $(34.4 \%)$ & 23 & $(23.5 \%)$ & \\
\hline Divorced & 50 & $(19.8 \%)$ & 28 & $(18.2 \%)$ & 22 & $(22.4 \%)$ & \\
\hline Widower & 4 & $(1.6 \%)$ & 2 & $(1.3 \%)$ & 2 & $(2.0 \%)$ & \\
\hline \multicolumn{8}{|l|}{ Education } \\
\hline None & 28 & $(11.2 \%)$ & 15 & $(9.8 \%)$ & 13 & $(13.3 \%)$ & \multirow{4}{*}{1.4} \\
\hline Primary school & 135 & $(53.8 \%)$ & 81 & (52.9\%) & 54 & $(55.1 \%)$ & \\
\hline Secondary school & 62 & $(24.7 \%)$ & 41 & $(26.8 \%)$ & 21 & $(21.4 \%)$ & \\
\hline University & 26 & $(10.4 \%)$ & 16 & $(10.5 \%)$ & 10 & $(10.2 \%)$ & \\
\hline \multicolumn{8}{|l|}{ Employment situation } \\
\hline Employed & 166 & $(65.9 \%)$ & 109 & $(70.8 \%)$ & 57 & $(58.2 \%)$ & \multirow{3}{*}{4.3} \\
\hline Unemployed & 68 & $(27.0 \%)$ & 35 & $(22.7 \%)$ & 33 & $(33.7 \%)$ & \\
\hline Others (student. retired. etc.) & 18 & $(7.1 \%)$ & 10 & $(6.5 \%)$ & 8 & $(8.2 \%)$ & \\
\hline \multicolumn{8}{|l|}{ Substance } \\
\hline Alcohol & 109 & $(43.3 \%)$ & 59 & $(38.3 \%)$ & 50 & $(51.0 \%)$ & \multirow{3}{*}{$6.4^{*}$} \\
\hline Cocaine & 125 & $(49.6 \%)$ & 80 & $(51.9 \%)$ & 45 & $(45.9 \%)$ & \\
\hline Others (heroin. cannabis...) & 18 & $(7.1 \%)$ & 15 & $(9.7 \%)$ & 3 & $(3.1 \%)$ & \\
\hline Another substance abuse & 64 & $(25.4 \%)$ & 43 & $(27.9 \%)$ & 21 & $(21.4 \%)$ & 1.3 \\
\hline Alcohol & 15 & $(6.0 \%)$ & 8 & $(18.6 \%)$ & 7 & $(33.3 \%)$ & \\
\hline Cocaine & 28 & (11.1\%) & 14 & (32.6\%) & 6 & (28.6\%) & 1.7 \\
\hline Others & 21 & $(8.3 \%)$ & 21 & $(48.8 \%)$ & 8 & $(38.1 \%)$ & \\
\hline
\end{tabular}

${ }^{*} p<.05$

López-Goñi, J.J., Fernández-Montalvo, J. y Arteaga, A. (2012). Predictive validity 22 of the EuropAsi: Clinical diagnosis or composite scoring? Journal of Substance

Abuse Treatment, 42, 392-399. http://dx.doi.org/10.1016/j.jsat.2011.09.011 
Table 2. Description of the Interviewer Severity Ratings (ISR), Composite Scoring (CS) and a comparison between discharge and dropout rates

\begin{tabular}{|c|c|c|c|c|c|c|}
\hline & & $\begin{array}{c}\text { All } \\
(\mathrm{N}=252)\end{array}$ & $\begin{array}{c}\text { Therapeutic discharge } \\
(\mathrm{n}=154)\end{array}$ & $\begin{array}{c}\text { Drop-out } \\
(\mathrm{n}=98)\end{array}$ & & \\
\hline & & $M(S D)$ & $M(S D)$ & $M(S D)$ & $t$ & $d f$ \\
\hline \multirow{7}{*}{$\begin{array}{l}\text { EuropASI } \\
\text { ISRs }\end{array}$} & Medical & $2.0(1.4)$ & $2.0(1.4)$ & $2.0(1.3)$ & .1 & 250 \\
\hline & Employment/Support & $2.4(1.7)$ & $2.2(1.6)$ & $2.6(1.8)$ & 1.9 & 185.1 \\
\hline & Alcohol use & $3.9(2.0)$ & $3.7(1.9)$ & $4.2(2.0)$ & $2.2^{*}$ & 250 \\
\hline & Drug use & $3.4(2.1)$ & $3.6(2.0)$ & $3.0(2.2)$ & $2.4^{*}$ & 249 \\
\hline & Legal & $1.8(1.5)$ & $1.9(1.5)$ & $1.6(1.3)$ & 1.4 & 250 \\
\hline & Family/Social & $3.7(1.7)$ & $3.3(1.7)$ & $4.2(1.6)$ & $4.0 * *$ & 249 \\
\hline & Psychiatric & $3.2(1.7)$ & $3.0(1.7)$ & $3.5(1.8)$ & $2.0 *$ & 250 \\
\hline \multirow{9}{*}{$\begin{array}{l}\text { EuropASI } \\
\text { CS }\end{array}$} & Medical & $.22(.25)$ & $.20(.25)$ & $.25(.26)$ & 1.3 & 250 \\
\hline & Economic situation & $.38(.45)$ & $.35(.44)$ & $.43(.46)$ & 1.4 & 250 \\
\hline & Satisfaction & $.27(.32)$ & $.24(.30)$ & $.32(.35)$ & $1.9 *$ & 250 \\
\hline & Alcohol & $.31(.24)$ & $.27(.21)$ & $.38(.26)$ & $3.6^{* *}$ & 250 \\
\hline & Drug use & $.13(.12)$ & $.10(.08)$ & $.10(.09)$ & .2 & 176.6 \\
\hline & Legal & $.11(.19)$ & $.13(.21)$ & $.11(.21)$ & .4 & 249 \\
\hline & Family & $.27(.23)$ & $.24(.23)$ & $.31(.23)$ & $2.5^{*}$ & 250 \\
\hline & Others & $.15(.18)$ & $.14(.17)$ & $.17(.20)$ & 1.3 & 248 \\
\hline & Psychiatric & $.21(.19)$ & $.19(.17)$ & $.24(.21)$ & 1.9 & 175.1 \\
\hline
\end{tabular}


Table 3. Correlations between the Interviewer's Severity Ratings and the Composite Scores of the EuropAsi at the beginning of the treatment.

\begin{tabular}{|c|c|c|c|c|c|c|c|c|c|}
\hline \multirow{3}{*}{ Interviewer's Severity Ratings } & \multicolumn{9}{|c|}{ Composite Scores } \\
\hline & \multirow[t]{2}{*}{ Medical } & \multicolumn{2}{|c|}{ Employment } & \multirow[t]{2}{*}{ Alcohol } & \multirow[t]{2}{*}{ Drug use } & \multirow[t]{2}{*}{ Legal } & \multicolumn{2}{|c|}{ Family } & \multirow[t]{2}{*}{ Psychiatric } \\
\hline & & Economic Situation & Satisfaction & & & & Family & Others & \\
\hline Medical & $.614^{* *}$ & $.151 *$ & $.181^{* *}$ & .054 & -.060 & -.029 & $.141^{*}$ & .042 & $.151^{*}$ \\
\hline Employment & $.232 * *$ & $.530 * *$ & $.636 * *$ & .019 & -.023 & .050 & .111 & .101 & $.174^{* *}$ \\
\hline Alcohol use & $.162 * *$ & $.317 * *$ & .084 & $.552 * *$ & $-.335^{* *}$ & .020 & $.199 * *$ & .016 & $.249 * *$ \\
\hline Drug use & -.045 & .054 & .018 & $-.216^{* *}$ & $.728 * *$ & -.037 & .046 & $.182 * *$ & .094 \\
\hline Legal & .051 & .114 & .007 & -.057 & $.143 *$ & .014 & .002 & .098 & .113 \\
\hline Family/Social & $.140 *$ & $.313^{* *}$ & $.147 *$ & .111 & .048 & -.059 & $.539 * *$ & $.367 * *$ & $.341^{* *}$ \\
\hline Psychiatric & $.196 * *$ & $.237 * *$ & $.177 * *$ & $.143 *$ & .004 & .075 & $.174 * *$ & $.298 * *$ & $.671^{* *}$ \\
\hline
\end{tabular}

$* p<.05 ; * * p<.01$ 
Table 4. Multivariable analysis for the ISR, the CS, and the ISR together with the CS (logistic regression and CHAID analysis).

\begin{tabular}{|c|c|c|c|c|c|c|c|c|c|}
\hline \multirow[b]{3}{*}{ STEP } & \multicolumn{9}{|c|}{ Logistic Regression (Dep. var = Drop-out) } \\
\hline & \multicolumn{3}{|c|}{ Model 1: (IV) = ISR } & \multicolumn{3}{|c|}{ Model 2: (IV) = CS } & \multicolumn{3}{|c|}{ Model 3: (IV) = ISR + CS } \\
\hline & Var. & OR & $95 \% \mathrm{CI}$ & Var. & OR & $95 \% \mathrm{CI}$ & Var. & OR & $95 \% \mathrm{CI}$ \\
\hline $\begin{array}{l}1 \\
2 \\
3 \\
4\end{array}$ & $\begin{array}{l}\text { Family } \\
\text { Drugs }\end{array}$ & $\begin{array}{l}.740 \\
1.22\end{array}$ & $\begin{array}{c}(.63, .87) \\
(1.01,1.39)\end{array}$ & $\begin{array}{l}\text { Alcohol } \\
\text { Family }\end{array}$ & $\begin{array}{l}.13 \\
.28\end{array}$ & $\begin{array}{l}(.04, .40) \\
(.05, .47)\end{array}$ & $\begin{array}{l}\text { CS Alcohol } \\
\text { ISR Family } \\
\text { ISR Drugs } \\
\text { CS Drugs }\end{array}$ & $\begin{array}{c}.13^{* * *} \\
.76^{* *} \\
1.16^{*} \\
0 * *\end{array}$ & $\begin{array}{c}(.04, .41) \\
(.65, .90) \\
(1.01,1.33) \\
(.0, .06)\end{array}$ \\
\hline $\begin{array}{l}\text { Final model } \\
\text { Full model adj. } \mathrm{R}^{2}\end{array}$ & $\begin{array}{l}\text { Drugs } \\
\text { Family } \\
\text { Constant }\end{array}$ & $\begin{array}{l}1.22 * * \\
.71^{* * *} \\
2.9 * *\end{array}$ & $\begin{array}{c}(1.07,1.4) \\
(.60, .83)\end{array}$ & $\begin{array}{l}\text { Alcohol } \\
\text { Family } \\
\text { Constant } \\
\\
\\
.097 \\
\end{array}$ & $\begin{array}{c}.15^{* *} \\
.28^{*} \\
4.1^{* * *}\end{array}$ & $\begin{array}{l}(.05, .47) \\
(.09, .9)\end{array}$ & $\begin{array}{l}\text { CS Alcohol } \\
\text { ISR Family } \\
\text { ISR Drugs } \\
\text { CS Drugs } \\
\text { Constant } \\
.204\end{array}$ & $\begin{array}{c}.20^{* *} \\
.71^{* * *} \\
1.49^{* * *} \\
.0^{* *} \\
5.4^{* * *}\end{array}$ & $\begin{array}{c}(.06, .66) \\
(.59, .84) \\
(1.20,1.84) \\
(.0, .06)\end{array}$ \\
\hline & \multicolumn{9}{|c|}{ CHAID analysis } \\
\hline & \multicolumn{9}{|c|}{ Therapeutic Discharge = 154 (61.1\%); Drop-out = 98 (38.9\%) } \\
\hline & \multicolumn{3}{|c|}{ Model 1: (IV) = ISR } & \multicolumn{3}{|c|}{ Model 2: (IV) = CS } & \multicolumn{3}{|c|}{ Model 3: $($ IV) $=$ ISR + CS } \\
\hline & \multicolumn{3}{|c|}{$\begin{array}{c}\text { Corrected } \mathrm{P} \text { value }=0.000 \\
X^{2}=18.080(\mathrm{gl}=1)\end{array}$} & \multicolumn{3}{|c|}{$\begin{array}{c}\text { Corrected } \mathrm{P} \text { value }=0.008 \\
\quad X^{2}=10.938(\mathrm{gl}=1)\end{array}$} & \multicolumn{3}{|c|}{$\begin{array}{c}\text { Corrected } \mathrm{P} \text { value }=0.000 \\
X^{2}=18.080(\mathrm{gl}=1)\end{array}$} \\
\hline & \multicolumn{2}{|c|}{ Family $<=3$} & Family > 3 & Alcoho & $<=0.34$ & Alcohol > 0.34 & \multicolumn{2}{|c|}{ Family $<=3$} & Family $>3$ \\
\hline & \multicolumn{2}{|c|}{$\mathrm{n}(\%)$} & $\mathrm{n}(\%)$ & & $\%)$ & $\mathrm{n}(\%)$ & \multicolumn{2}{|c|}{$\mathrm{n}(\%)$} & $\mathrm{n}(\%)$ \\
\hline Drop-out & \multicolumn{2}{|c|}{$31(25.4 \%)$} & $67(51.5 \%)$ & 47 & $0.7 \%)$ & $51(51.5 \%)$ & \multicolumn{2}{|c|}{$31(25.4 \%)$} & $67(51.5 \%)$ \\
\hline Therapeutic Discharge & \multicolumn{2}{|c|}{$91(74.6 \%)$} & $63(48.5 \%)$ & 106 & $59.3 \%)$ & $48(48.5 \%)$ & \multicolumn{2}{|c|}{$91(74.6 \%)$} & $63(48.5 \%)$ \\
\hline Total & \multicolumn{2}{|c|}{$122(48.4 \%)$} & $130(51.6 \%)$ & 153 & $50.7 \%)$ & 99 (39.3\%) & \multicolumn{2}{|c|}{$122(48.4 \%)$} & $130(51.6 \%)$ \\
\hline
\end{tabular}

IV = Independent Variables; ISR = Interviewer Severity Ratings; CS = Composite Scores

${ }^{*} p<.05 ; * * p<.01 ; * * * p<.001$

López-Goñi, J.J., Fernández-Montalvo, J. y Arteaga, A. (2012). Predictive validity of the EuropAsi: Clinical diagnosis or composite scoring? 25 Journal of Substance Abuse Treatment, 42, 392-399. http://dx.doi.org/10.1016/j.jsat.2011.09.011 